\title{
Woods or Trees? Ideas and Actors in the History of Science
}

\section{Citation}

Rosenberg, Charles E. 1988. Woods or trees? Ideas and actors in the history of science. Isis 79(4): 564-570.

\section{Published Version}

doi:10.1086/354844

\section{Permanent link}

http://nrs.harvard.edu/urn-3:HUL.InstRepos:4730414

\section{Terms of Use}

This article was downloaded from Harvard University's DASH repository, and is made available under the terms and conditions applicable to Other Posted Material, as set forth at http:// nrs.harvard.edu/urn-3:HUL.InstRepos:dash.current.terms-of-use\#LAA

\section{Share Your Story}

The Harvard community has made this article openly available.

Please share how this access benefits you. Submit a story.

Accessibility 


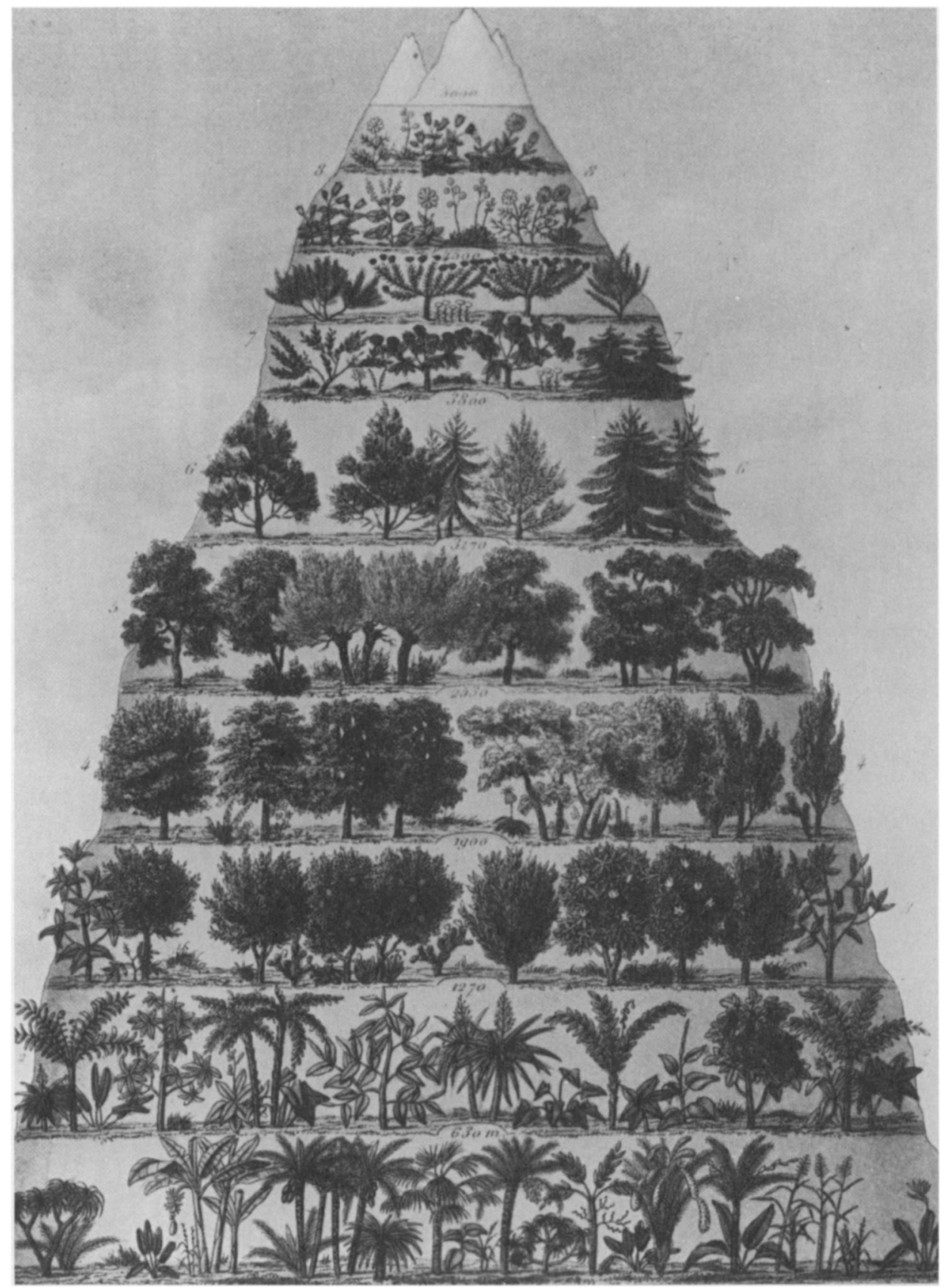

A schematic representation of how types of vegetation vary with altitude. From A. Dupuis, Fr. Gérard, $O$. Reveil, $F$. Hérincq, Le regne végétal, divisé en traité de botanique générale, Flore médicale et usuelle, horticulture botanique et pratique ... (Paris, [1864-1869]), Vol. I, Plate 6. 


\section{EDITORIAL}

\section{Woods or Trees?}

\section{Ideas and Actors in the History of Science}

$\mathrm{W}$ HEN I BEGAN to learn a bit about the history of science a quarter century ago, I discovered that the field was much agitated about the difference between what were called internal and external approaches. No one defended the distinction; in fact, most deplored it-and have continued to do so-but it remains an issue.

In the past quarter century the problem has been transformed. Externalists were defensive and of lowly status in the early 1960s. Since then an articulate minority of sociologists and historians has constructed more self-conscious and in some cases explicitly relativist "externalisms" that are perceived as impugning the privileged status of scientific knowledge, that seem to question the cognitive autonomy of science as ultimately and categorically insulated from its context.

In the past decade, however, the great majority of historical practitioners have come to occupy increasingly nuanced and eclectic positions. We can all agree. The problem is not context as opposed to cognition, but understanding the structure of their integration. That integration nonetheless remains a continuing problem of interpretation, if not an accurate description of sectarian identities.

Yet historical practice still reflects primary-and analytically dysfunctionalloyalties to one camp or another; one scholar's foreground is another's background. My own experience as editor of Isis has emphasized how few historians of science succeed in relating ideas to social and institutional contexts; many are unwilling to try. Most articles still fall unambiguously into one or the other category.

What then is the basis for this long-standing difference in emphasis? To a significant extent it reflects a particular subdisciplinary tradition; historians of science are still recruited from diverse backgrounds and individuals enter the field with different agendas, disparate investments in technical preparation, and contrasting standards of achievement. And, as we are well aware, the past generation has seen a politically charged and polarizing debate over the social basis and consequences of science and technology, over the putative role of ideas and of the experts who articulate them in a hegemonic imposition of social control. It is hardly surprising that these emotional and political differences should have spilled over into the relatively quiet confines of academic history.

But differences over appropriate method and subject matter reflect a far more

These remarks were prepared for presentation at a conference marking the fiftieth anniversary of Harvard's Department of the History of Science, 20 February 1988. This revision has benefited from the comments of Drew Gilpin Faust, John L. Heilbron, Thomas S. Kuhn, Mary Jo Nye, Steven Shapin, and Jeffrey L. Sturchio. 
fundamental distinction, one that transcends internal differences among those men and women who think of themselves as historians of science. It is the difference between what some anthropologists call emic and etic. Emic approaches are rooted in the attempt to understand a culture distant in time or space as it is perceived and experienced by its members, while etic approaches see as fundamental a higher, realer reality, an organizing structure that transcends the reality perceived and negotiated by the subjects of one's investigation. I would suggest that a developing structure of scientific ideas is one form of such transcendent framework, a pattern of economic development and class relations in a traditional Marxist formulation another. In philosophy, fundamental problems of metaphysics, epistemology, or scientific method constitute another such framework that informs even the work of those scholars who call themselves historians of philosophy. From the perspective of most contemporary scientists, the historical actor's perceptions and social location are not without interest but are ultimately significant only insofar as they relate to that actor's place in an evolving pattern of cognitive understanding. It is a quintessentially etic point of view. Interest in the structure of professional ambitions, or a time-bound context of education and practice, becomes a kind of antiquarianism: these topics are seen as significant not in themselves but for their relationship to a more fundamental pattern of cognitive development. In this etic perspective, all consciousness is in a measure false consciousness, its ultimate meaning to be derived from its relation to a larger structure, whether social or cognitive. Much of the excitement surrounding Thomas S. Kuhn's Structure of Scientific Revolutions a quarter century ago grew out of polarized reactions to its pragmatic-and programmatic-attempt to integrate the emic and etic, the temporal and eternal, to show the relationship between the time-blindered and disciplinary-community-oriented actor and the ideas that retrospectively legitimated his or her place in a canon of accomplishment. We are discussing, in other words, a fundamental difference between the necessary and the contingent, the product and the process of its production, the abstracted and the embedded.

This is not to argue that internalist positions are necessarily etic, externalist emic. Although there is, I am convinced, a somewhat greater tendency for internalist scholarship to reflect an etic point of view, sociologists and social historians often impose their own style of etic analysis as well, focusing, for example, on issues such as "professionalization," or the evolution of institutional forms.

But common sense and the best historical practice tell us that good historians have always sought to employ and integrate both emic and etic perspectives-to see both woods and trees. This means reconstructing the choices, sharing the same assumptions and organizing ideas as past actors even if we see those actors as at some level unknowing integers in a larger calculus. It means using perceptions removed from the historian by time or cultural distance as both substantive element and analytic tool in construing larger structures often opaque to the objects of one's research. Even if a historian pursues etic ends, they must often be attained through emic means, by reconstructing the experience of particular actors in the past. Inaccurate perceptions and incorrect hypotheses are substantive factors, inasmuch as they constitute an aspect of experience, inspire thought, and compel social action.

In the history of science an actor-oriented approach is necessarily intellectual 
as well as social and institutional. As an intellectual, a scientific actor's choices, even if structured by institutional locations, are at some level cognitive. Ideasand very specific ones at that-are fundamental to his or her identity as scientist; and part of that identity is the awareness that intellectual work will constitute the retrospective measure of a life's achievement. Understanding cognitive options from the past scholar's point of view is thus a fundamental research task. Embeddedness is a necessity-for the historian of science as well as for the social or political historian. I have already suggested that a central problem in the history of science was not context as opposed to cognition, but understanding the structure of their integration. And at some level that integration necessarily took place in the heads and hearts of individual actors, men and women as they made career choices, identified with a particular discipline or subdiscipline, approached technical problems, and evaluated their findings.

These remarks should be understood as being addressed to the historian's humble job of work, not to the formulation or solution of problems in epistemology or the philosophy of science. ${ }^{1}$ I am neither naive nor utopian enough to think that historians can, in fact, reconstruct an actor's perceived world-or even succeed in forgetting what we know about subsequent progress in the understanding of natural phenomena. Nor am I trying to argue for the biography as a privileged type of endeavor in the history of science. What I am trying to suggest is something rather more mundane and operational: by looking systematically at the past through an actor's life course, we necessarily follow a checklist of relevant choices as perceived by that actor (or actors). Even if one is interested, let us say, in an institution, that institution must function through its rewards and expectations as perceived and understood by those who responded to them. ${ }^{2}$ Institutions are not reducible to tables of organization or budget lines; they are made real by the perceptions, actions, and commitments of particular men and women who function within them. The same kind of remarks apply to disciplines and subdisciplines as well-and in fact to institutions generally. If one is concerned with the development of particular ideas and techniques one must be equally concerned with those past individuals who oriented their work and ambitions around that set of problems. If one is ultimately committed to the discipline of history and values historical practice, then one must necessarily be interested in specific past actors, their perceived choices and constraints no matter what one's particular focus of research.

Let me illustrate the implications of an actor-oriented approach by some reference to my own experience. I have been particularly influenced by my own choice of research options, most importantly by an investigation of midnineteenth-century American agricultural chemists that I undertook a quarter

\footnotetext{
${ }^{1}$ In this brief compass I have not addressed the related problem of exposition and narrative. I am concerned instead with a style of formulating research and conducting an appropriate research plan - one consistent with a variety of theoretical and disciplinary orientations. For example, important recent studies by Martin Rudwick (The Great Devonian Controversy, The Shaping of Scientific Knowledge among Gentlemanly Specialists [Chicago/London: Univ. Chicago Press, 1985]) and Steven Shapin and Simon Schaffer (Leviathan and the Air-Pump: Hobbes, Boyle, and the Experimental Life [Princeton: Princeton Univ. Press, 1985]) might both be said to exemplify actor-oriented approaches. But they are very different books; the authors' differing analytical goals implied very different expository and narrative strategies.

${ }^{2}$ I have made some related suggestions, in "Science in American Society: A Generation of Historical Debate," Isis, 1983, 74:356-367.
} 
century ago. When I read their letters, diaries, and memoranda, as well as their articles and speeches, it was impossible not to try to reconstruct their world as they themselves faced it and as they tried to steer a successful course among its shoals. This handful of institutional innovators was influenced by the scientific ideals and specific problem sets of Göttingen and Heidelberg in the 1840s and 1850 s, yet motivated by a peculiarly American and pietistic commitment to moral improvement and the life of the mind. Their peculiar commitment was to prove an agent of change in the growth of higher education and our agricultural economy. The connections between the laboratory and an ultimate context of application were brought together and made real by particular actors fashioning careers for themselves-yet conforming to disciplinary patterns established in a larger intellectual world. In this sense ideas and disciplines become actors as well, acting in and on a particular social and economic system. These agricultural chemists can be seen as a point of insertion for new-and ultimately significant -roles and research agendas in a culture generally inhospitable to the laboratory and the academy. Specific ideas and academic values exist, that is, not in some realm of disembodied cognition but in the minds and emotional priorities of particular individuals.

Some of my more recent work on the medical profession in relation to the hospital has underlined the significance of similar relationships. In both cases, institutional forms have developed in a kind of symbiosis with the structuring and informing role of career-driven and career-oriented individuals. In both cases, moreover, the context of application (clinical medicine and agricultural productivity) and the context of knowledge production and reproduction (research and teaching) have generated an intricate and historically determined relationship, one that has had enormous ultimate impact not only in the realm of markets and institutions but inevitably in that of "basic science" as well. The hospital became in some ways the product of particular intellectual and institutional developments in medicine-of the growth of the specialties, of mechanism-oriented models of disease, and of the expanded role of technology generally. The interdependence of perceived career options, ideas, and the hospital as social institution not only is an extraordinarily important aspect of the history of medicine but is exemplary of a good many other crucial relationships between modern intellectual life and the society that supports such activity. From another point of view, it illustrates a patterned integration of context and cognition in which change turns on the parallel interaction of individual and institutional factors.

Some critics will contend that such discussion of career patterns and applied science evades the issues of innovation and change that remain the intellectual and emotional center of science and of its history. I would respond that an actororiented, life-course-structured point of view is particularly appropriate to the would-be elucidator of scientific ideas. What can we do, after all, other than reconstruct as best we can the intellectual and institutional options that faced particular individuals or groups of individuals? We cannot with confidence address the ultimate questions of idiosyncrasy and discovery: what used to be called genius is, I feel, too intangible to serve as a promising subject for historical analysis. What the historian must seek to understand is the way in which an Einstein or a Maxwell shared their contemporaries' knowledge and problem 
agendas; such analysis is less problematic than the more speculative attempt to comprehend the personal equation that allowed them to redefine those options. (And even if one is valiant enough to probe the essence of an individual's creativity, the reconstruction of a protagonist's institutional and intellectual environment remains a necessary precondition.) An actor-oriented approach seeks to appropriate the individual in the service of transcending the individual and thus the idiosyncratic; it seeks to use an individual's experience as a sampling device for gaining an understanding of the structural and normative. ${ }^{3}$

But perhaps this is belaboring the obvious; to some extent we have become an audience of the converted. It is now fashionable to study subdisciplinary formation, laboratory life, and scientific practice to bring, for example, the implicitly relativistic tools of ethnography to science, even to the once-sacred bastion of knowledge production and elaboration. In general history as well the past quarter century has seen historians move from public policy and elite experience to the behavior and ideas of ordinary men and women-to the microcosm of everyday life and experience. In this sense one can draw a useful parallel between the student of past laboratory practice or a physicist's graduate school training, on the one hand, and, on the other, the social historian of the household or the labor historian seeking to reconstruct the negotiated world of the shop floor.

Yet a kind of dialectic is already manifesting itself. We are already beset by calls for a return to the traditional "big questions" of social change and state policy-even moral judgment- that have so long concerned and motivated historians. Historians of science too must respond to this need to move from the particular to the general, from the individual actor to broader patterns of intellectual and institutional development. The relationship between the particular and general, between meaning and structure, has always been a key to historical understanding; it is a tension that constitutes both a fundamental aspect of reality and an elusive challenge to social science method.

The woods and trees metaphor is particularly apt in this connection. The contemporary ecologist's conception of a particular woods assumes and necessitates an understanding of the trees-their species, their climatic and nutritional needs; woods and trees are in this sense indistinguishable in some sense as interactive system and as a linked research agenda. ${ }^{4}$ We too must disentangle and specify in our particular sphere the relationships between the actor's perceptions and strivings, his or her institutional climate, the soil that nurtures-or fails to nurtureparticular career and cognitive options. And we must also move this style of analysis into society from the laboratory and library, to evaluate the dissemination and ultimate impact of the products of cognition. We cannot understand the modern world without an understanding of those necessary connections between the individual and his or her discipline, between the discipline and the social

\footnotetext{
${ }^{3}$ This is not to denigrate biography as genre or prescribe a particular style of biography. I would argue, however, that unless the would-be biographer tries to reconstruct a protagonist's social world in emic terms-to write a life in a very particular time-he or she will hardly succeed in explaining that subject's actions or evaluating the motives that impelled them.

${ }^{4}$ Cf. Charles E. Rosenberg, "Towards an Ecology of Knowledge," in The Organization of Knowledge in Modern America, 1860-1920, ed. Alexandra Oleson and John Voss (Baltimore: Johns Hopkins Univ. Press, 1979), pp. 440-455.
} 
sources of its support, between ideas and their real impacts in a real world. It is these interactions at least that originally attracted me to the field and which remain in enticing measure unexplored.

Sometimes one wonders whether the history of science is a coherent discipline or just a collection of scholars aggregated by the accidents of history and the accretion of a common historiography. And in some sense we are indeed a diverse lot, a kind of mosaic, each component tile discrete and isolated. But at the same time we are bound together by certain thematic unities, like any wellcomposed mosaic, and one of those integrating unities is precisely the structured tension between the external and internal. It is not a problem that can be "solved" but a condition of our collective identity.

Charles Rosenberg September 1988

\section{ZEITLIN-VER BRUGGE PRIZE}

The History of Science Society announces the sponsorship, through the generosity of Jacob Zeitlin and Josephine Ver Brugge of Los Angeles, of its prize to encourage the publication in Isis of original research of the highest standard. Consisting of $\$ 250$ and a certificate, this prize is given annually, on the recommendation of the Committee on Isis, to the author of the best article in Isis in three years prior to the award.

Prize winners:

1979 Robert Nye, "Heredity or Milieu: The Foundations of European Criminological Theory," Isis, 1976, 67:335-355

1980 Thomas L. Hankins, "Triplets and Triads: Sir William Rowan Hamilton on the Metaphysics of Mathematics," Isis, 1977, 68:175-193

1981 Linda E. Voigts, "Anglo-Saxon Plant Remedies and the AngloSaxons," Isis, 1979, 70:250-268

1982 Timothy Lenoir, "Kant, Blumenbach, and Vital Materialism in German Biology," Isis, 1980, 71:77-108.

1983 Alexander Vucinich, "Soviet Physicists and Philosophers in the 1930s: Dynamics of a Conflict," Isis, 1980, 71:236-250.

1984 James Secord, "Nature's Fancy: Charles Darwin and the Breeding of Pigeons," Isis, 1981, 72:163-186.

1985 Keith Hutchison, "What Happened to Occult Qualities in the Scientific Revolution? Isis, 1982, 73:233-253.

1986 Mara Beller, "Matrix Theory Before Schrödinger: Philosophy, Problems, Consequences," Isis, 1983, 74:469-491.

1987 Richard S. Westfall, "Scientific Patronage: Galileo and the Telescope," Isis, 1985, 76:11-30.

The next award will be made in December 1988, and articles published in Isis from March 1985 to December 1987, inclusive, will be eligible. 